\title{
Eğitim fakültelerindeki araştırma görevlilerinin mesleki deneyimlerinin incelenmesi: araştırma görevlisi olmanın anlamına ilişkin fenomenolojik bir çalışma
}

\author{
Kaya YILMAZ ${ }^{[*]}$ \\ Taner ŞAHIN $\left.{ }^{[*}\right]$
}

\section{Öz}

Alan yazında araştırma görevlilerinin mesleklerini nasıl algıladıklarının yeterince bilinmediği vurgulanmıştır. Günümüze kadar yapılan çalışmalarda araştırma görevlilerinin mesleklerini nasıl anlamlandırdıkları fenomenolojik araştırma deseni ile henüz incelenmemiştir. Literatürdeki eksikliği gidermeyi amaçlayan bu çalışmada, araştırma görevlilerinin kendi yaşantı ve deneyimlerine dayalı olarak araştırma görevlisi olmanın anlamı incelenmiştir. Fenomenolojk araştırma deseni ile yürütülmüş olan çalışma, araştırma görevlilerinin mesleğe yönelik algılarını ve çalışma hayatında yaşadıkları deneyimleri nasıl anlamlandırdıklarını ortaya koyması açısından önemlidir. Araştırmanın katılımcı grubu, eğitim fakültesinde araştırma görevlisi olarak çalışan 10 kişiden oluşmaktadır. Araştırma verileri açık uçlu sorulardan oluşan yarı yapılandırılmış görüşme tekniği kullanılarak toplanmıştır. Görüşmede katılımcıların verdikleri cevaplara bağlı olarak sonda soruları da sorulmuştur. Fenomenolojik çalışmada incelenen araştırma konusuna ilişkin katılımcıların deneyimlerinin özüne ve yapısına ulaşmak hedeflenmektedir. Bu nedenle, katılımcıların araştırma görevlisi olma deneyimlerinin özünü ve yapısını açığa çıkarmak amacılyla verilerin analizinde 'parantezleme','fenomenolojik redüksiyon','imgesel çeşitleme' ve 'anlam ve özlerin sentezlenmesi' olmak üzere dört aşamalı bir süreç takip edilmiştir. Verilerin analizi sonucunda eğitim fakültesinde araştırma görevlisi olma fenomeninin yapısını ve özünü birbiriyle ilişkili altı bileşenin oluşturduğu tespit edilmiştir. Deneyimin yapısını oluşturan bu bileșenler veya özler; araştırma görevlilerinin (1) istismar edilmesi, sekreterlik ve angarya işler yapması, (2) akademik baskıyla karşılaşması, (3) ekonomik sıkıntılarla yüzleşmesi, (4) motivasyon kaybı yaşaması, (5) akademik kariyer yapması ve (6) akademik gelişim sağlamasıdır. Araştırma görevlileri, görev tanımlarında olmadığı halde evrak ve angarya işleri yaptıklarını, hocaların yerine derslere girdiklerini ve onların özel işlerini yaptıklarını, bu durumun kendilerini rahatsız ettiğini ve kullanıldıklarını düşündüklerini belirtmişlerdir. Araştırma görevlilerinin akademik çalışmalarında da yeterince özgürce hareket edemedikleri, çalışmalarında baskı ve müdahale ile

[*] Prof. Dr., Marmara Üniversitesi, Atatürk Eğitim Fakültesi, Sosyal Bilgiler Eğitimi Anabilim Dall, kaya.yilmaz@marmara.edu.tr

${ }^{[*}$ Doktora Öğrencisi, Marmara Üniversitesi Eğitim Bilimleri Enstitüsü, Sosyal Bilgiler Eğitimi, tanersahin8@gmail.com 
karşılaştıkları, özel ve mesleki hayatlarında ekonomik sorunlarla karşılaştıkları, tüm bu sorunların kendilerinde motivasyon kaybına neden olduğu belirlenmiştir. Araştırma görevlilerinin mesleklerinde edindikleri deneyimlerin, akademik kimlik inşa etme sürecinde önemli bir rol oynadığı tespit edilmiştir. Son olarak akademik kariyer ve bilimsel çalışmalar yapmanın araştırma görevlilerine mutluluk verdiği, onların akademik gelişimlerine katkıda bulunduğu tespit edilmiştir.

Anahtar kelimeler: Araştırma görevlisi, eğitim fakültesi, fenomenolojik çalışma

\title{
An examination of the professional experience of research assistants serving in college of education: a phenomenological study of the meaning of being a research assistant
}

\begin{abstract}
It is emphasized in the previous studies that little, if any, has been known about how research assistants perceive their occupation. This research topic has not been examined via phenomenological research design. Aimed at addressing this gap in the literature, this study examined how research assistants perceive their experiences as a research assistant. The study is significant in terms of its potential to reveal the participants' perceptions of what it means to be a research assistant on the basis of their own experiences. Phenomenological research design was used to conduct the study. The study participants were 10 research assistants who were employed at college of education. Semi-structured interview was used to collect data. Probing questions were asked to the participants depending on their answers to interview questions. Phenomenological study aims to reveal the essence and structure of a phenomenon experienced by participants. Therefore, in order to identify the meaning, essence and structure of the experience of being a research assistant, four intertwined processes were carried out during data analysis. These are 'bracketing', 'phenomenological reduction', 'imaginative variation' and 'synthesis of meanings and essences.' At the end of data analysis, it was found that the essence and structure of the phenomenon of being a research assistant at a college of education was composed of six interrelated components. Research assistants are (1) being exploited, doing secretary and drudgeries, (2) facing academic pressure, (3) confronting economic difficulties, (4) losing their motivation, (5) building an academic career, and (6) experiencing academic development. The participants have stated that even though it is not in their job definition, they are required to handle office works and chore, teach courses on behalf of the faculty members, do their personal works, and this situation makes them feel uncomfortable and exploited. It was found that research assistants do not have enough freedom in their academic affairs, confront interference and coercion by faculty members, face different sorts of economic hardship in their personal and academic life, and all of these negative experiences result in motivation loss for research assistants. Participants' statements have showed that experiences in carrying out research assistantship plays a significant role in their academic identity development. Lastly, engaging in academic career and conducting scientific research provide research assistants with intellectual satisfaction and contribute to their academic development.
\end{abstract}

Keywords: Research assistant, college of education, phenomenological study, 


\section{Giriş}

Bilginin önemli bir güç kaynağı haline geldiği günümüzde, küreselleşme ve teknolojik gelişmelerle birlikte bilgi akışı hızlanmıştır. $\mathrm{Bu}$ nedenle bilginin üretildiği en önemli kurumlardan biri olan üniversiteler önem kazanmıştır. Üniversiteler toplumun ihtiyaç duyduğu alanlarda nitelikli insanlar yetiştirme, araştırma, geliştirme, yayın ve patent yoluyla ülkelerin ekonomik, sosyal ve kültürel gelişmesinde önemli rol oynarlar. Kültürün geliştirilerek gelecek kuşaklara aktarılmasında ve toplumsal gelişme yoluyla sorunların çözülmesinde de üniversitelerin önemli yeri vardır (Aypay, 2006: 177; Arığlu ve Girgin, 2003). 2547 sayılı Yükseköğretim Kanunu’nun 4. maddesinde ülkemizde kurulan üniversitelerin amaçları ve işlevleri şu şekilde belirtilmektedir:

1. İlgi ve yetenekleri yönünde yurt kalkınmasına ve ihtiyaçlarına cevap verecek, aynı zamanda kendi geçim ve mutluluğunu sağlayacak bir mesleğin bilgi, beceri, davranış ve genel kültürüne sahip, vatandaşlar yetiştirmek,

2. Ülkenin refah ve mutluluğunu artırmak amacıyla; ekonomik, sosyal ve kültürel kalkınmasına katkıda bulunacak ve hızlandıracak programlar uygulayarak, çağdaş uygarlı̆̆ın yapıcı, yaratıcı ve seçkin bir ortağı haline gelmesini sağlamak,

3. Yükseköğretim kurumları olarak yüksek düzeyde bilimsel çalışma ve araştırma yapmak, bilgi ve teknoloji üretmek, bilim verilerini yaymak, ulusal alanda gelişme ve kalkınmaya destek olmak, yurt içi ve yurt dışı kurumlarla işbirliği yapmak suretiyle bilim dünyasının seçkin bir üyesi haline gelmek, evrensel ve çă̆daş gelişmeye katkıda bulunmaktır.

Yükseköğretim kurumlarında araştırma ve öğretim yapmakla görevli öğretim üyeleri, öğretim görevlileri, öğretim yardımcıları ve okutmanlar öğretim elemanlarını oluşturmaktadır (2547 sayılı YÖK Kanunu Md. 3). Yükseköğretim kurumlarında çalışan her kıdemdeki öğretim üyesinin niteliği özel olarak o kurumun genel olarak ise tüm kurumların ve ülkenin akademik yeterliliğinin de göstergesidir. Akademik yeterliliğin ülkenin gelişmesindeki önemli değişkenlerden biri olduğu dikkate alındığında, bu kurumlarda çalışan insan gücünün nitelikli olması gerektiği rahatlıkla anlaşılmaktadır. Ülkemizin sosyal, kültürel, ekonomik ve teknolojik alanlarda kalkınmasında motor işlevi gören üniversitelerin amaçlarını en iyi şekilde gerçekleştirebilmesi nitelikli öğretim elemanlarının yetiştirilmesi ile mümkündür.

Akademisyenler, gelecek nesillerin şekillendirilmesinde önemli işlevleri yerine getirmektedir (Boylu vd.,2007: 56). Akademik kariyer basamaklarının ilk adımını ve öğretim üyeliğine girişin başlangıcını lisansüstü düzeyinde öğrenim yapan araştırma görevlileri oluşturur (Yaya, 2011: 26). 2547 Sayılı Yüksek Öğretim Kanunu’nun 33. Maddesinde araştırma görevlileri, öğretim yardımcıları sınıfında yer almaktadır. Araştırma görevliliğinin görev tanımı "yükseköğretim kurumlarında yapılan araştırma, inceleme ve deneylerde yardımcı olan ve yetkili organlarca verilen ilgili diğer görevleri yapan öğretim yardımcılarıdır” şeklinde yapılmıştır (YÖK, 1981). 
Öğretim üyeliği kadrolarının kaynağını araştırma görevlileri teşkil etmektedir (Korkut ve diğerleri, 1999). Akademisyenliğe yönelik algı, tutum ve değer yargıları araştırma görevliliğ̈i döneminde oluşmaya başlamaktadır (Yaya, 2011: 2). Bu nedenle, üniversitelerin ihtiyaç duyduğu nitelikli öğretim üyelerinin yetiştirilmesinde araştırma görevliliğgi kadrosunun yeri ve önemi tartışılmazdır. Yükseköğretimin ihtiyaç duyduğu nitelikli insan gücünü karşılamadaki öneminden dolayı araştırma görevlilerinin akademik yaşantılarının ve algılarının bilinmesi önemlidir. Tüm akademik sürecin temeli olarak kabul edilen araştırma görevliliği döneminin çeşitli açılardan incelenmesi ve daha iyi anlaşılması gerekmektedir. Ülkemizde bu alanda yeterli çalışmanın yapıldığını söylemek mümkün değildir. Bu çalışma literatürdeki bu eksikliği gidermek amacıyla yapılmıştır. Aşağıdaki paragraflarda araştırma konusuyla ilgili yapılan çalışmalara yer verilmiştir.

Yapılan çalışmalar, akademisyenlerin iş yaşamında verimli ve üretken olabilmeleri, kendilerinden beklenen görevleri en iyi şekilde yerine getirebilmeleri için çalışma koşullarındaki olumsuz faktörlerin ortadan kaldırılması gerektiğini ortaya koymaktadır. Çalışma hayatı bireyi etkilerken birey de çalışma hayatını etkilemektedir. İşin kişi için ifade ettiği anlam ve birey-iş ilişkisinin temelinde ortaya çıkan olumlu-olumsuz tutumlar, çalışan kişinin mesleğine, kurumuna yönelik göstereceği tutumları etkilemektedir (Aytaç 2005: 836; Kuşdil vd., 2004). Çalışanın işe ve kuruma yönelik göstereceği olumlu tutumlar hem birey, hem de kurum açısından önemli görülmektedir. Çünkü çalışanın işini severek yapması, işindeki verimini ve kendi iyi olma durumunu etkilemekte, işini sevmeyerek yapması ise işini olumsuz etkileyerek strese yol açmaktadır (Aytaç 2005: 838). Çalı̧̧ma yaşamında meydana gelen bir durum çalışanın fiziksel, duygusal ve sosyal sağlığını, depresyon durumlarını ve zihinsel rahatsızlıklarını yakından etkilemektedir (Necşo1, 2011: 320). Bu bağlamda ülkenin ihtiyacı olan insan gücünü yetiştirme sorumluluğunu yüklenen yükseköğretim kurumları ve bu kurumlarda çalışan öğretim elemanlarının huzurlu ve verimli çalışabilmeleri, bilimsel bilgi üretimi ve nitelikli akademisyenler yetiştirilmesi açısından oldukça önemlidir (Baran ve Paliç, 2012: 96). Bu nedenle akademisyenlerin olumsuz bir durumla karşılaşmamaları için bazı çalışma koşullarına sahip olmaları gerektiği önceki çalışmalarda vurgulanmıştır.

Çalı̧̧ma yaşamında bulunması gereken koşullardan en önemlisi iş doyumudur. İş doyumu kavramı çalışanların işlerinde sağladığı başarılar sonucunda ve beklentileri karşılandığında hissettikleri olumlu duygusal durumlar olarak tanımlanabilir (İnandı, Tunç ve Uslu, 2013, s.222; Locke, 1968, s.10). İş doyumu üzerine yapılan araştırmalarda çalışanların iş doyumları ile kurumların başarısı arasında yakın bir ilişki olduğu, iş doyumunun verimliliği, yaratıcılı̆̆ 1 ve işe bağlllığı artırarak işten ayrılmaları azalttığı belirlenmiştir (İnand1, Tunç ve Uslu, 2013; Toker, 2011, s.156). Akademisyenlerin iş tutumunun olumlu olması, onların kurumlarına daha fazla katkıda bulunmalarını sağlamaktadır (Boylu vd., 2007: 56). İş doyumu, örgütsel bir değişken olarak iş motivasyonunu ve performansını da etkilemektedir. (Neç̧o1, 2011: 320; Terpstra \& Honoree, 2004: 528). Bu nedenle akademisyenlerin işlerini sevmeleri ve maddi ve manevi olarak tatmin olmaları gereklidir (Yılmaz ve Özdemir, 2012: 52). Çalışma yaşamının önemli değişkenlerinden biri de ekonomik koşullardır. Akademisyenlerin görevlerini 
etkili olarak yapabilmeleri için ekonomik durumlarının iyi olması ve ekonomik endişeler taşımamaları gerekmektedir. Araştırma görevlilerinin bu açıdan durumlarının hiç de iyi olmadığ yetersizliğin araştırma görevlileri için önemli bir sorun kaynağı olduğu tespit edilmiştir. Bu araştırmanın sonuçlarına göre, çalışmaya katılan 1534 araştırma görevlisinden \%65.5 kirada oturmakta, \%82'si üniversiteden ayrılmayı istemekte ve bu isteklerinin nedeni olarak maddi yetersizliği göstermektedir. Akagündüz (2012)'ün çalışmasında da araştırma görevlilerinin maaşlarının yetersiz olduğu, yüklü borç senetleri altında kamburlaştıkları ve maddi sıkıntılarla boğuştukları tespit edilmiştir. Araştırma görevlilerinin ekonomik sıkıntılar yaşadıkları Bakioğlu ve Yaman (2004)'nın çalışmasında da rapor edilmiştir.

Araştırma görevlilerin karşılaştıkları sorunlar sadece ekonomik yaşam koşullarının kötü olması ile sınırlı değildir. Korkut, Muştan ve Yalçınkaya (1999)'nın çalışmasında, araştırmaya katılan araştırma görevlilerinin \%92,5’nin yetki ve sorumluluk konusunda karmaşa yaşadıkları ve araştırma fonundan katkı alamadıkları belirlenmiştir. Ayrıca, iş tanımları arasında olmamasına rağmen araştırma görevlilerinin derslere girdikleri ve sekreterlik işleri yaptıkları da aynı araştırmanın bulguları arasında yer almaktadır. Başka bir çalışmada, araştırma görevlilerinin bedensel, sosyal ve çevre alanında yaşam kalitesinin düşük olduğu belirlenmiştir (Avcı ve Pala, 2004). Akagündüz (2012)'ün çalışmasında, araştırma görevlerinin kendilerini "köle" ya da "mahkum" olarak tanımladıkları, hocalarının özel işleri peşinde koşturdukları, hasta bakıcılık dahi yaptıkları, zaman zaman psikolojik tacize uğradıkları ve bu durumlar karşısında kendilerini çaresizlik içinde gördükleri belirlenmiştir. Kısa (2013)'nın çalışmasında da benzer sonuçlara ulaşılmış, araştırma görevlilerinin kendi mesleklerini "çıraklık ve sekreterliğe", "iş̧̧i arılara", "jokere", "çaresiz kişilere", "kölelere" ve "itaatkâr insanlara" benzettikleri ortaya çıkmıştır. Katılımcıların kullandıkları bu benzetmelere dayanılarak araştırma görevlilerinin görev belirsizliği ve üstlerle ilişkilerde sorunlar yaşadıkları ileri sürülmüştür. Araştırma görevlileri üzerine yapılan diğer çalışmalarda, araştırma görevlilerinin bölümlerinde rutin işler yapan memurlar olarak algılandıkları, akademik faaliyetler dışında işler yapmaya zorlandıkları, öğretim üyelerinin işlerini yaptıkları, bunun sonucunda kariyer gelişimlerinin olumsuz etkilendiği rapor edilmiştir (Bakioğlu ve Yaman, 2004; Bakioğlu ve Pekince, 2011).

\section{Araștırmanın amacı ve önemi}

$\mathrm{Bu}$ çalışmanın yukarıda özetlenen araştırmalardan farkı ve alan yazına katkısı, araştırma görevlerinin yaşadıkları deneyimleri fenomenolojik araştırma deseni ile ele alıp incelemesidir. Araştırma görevlilerinin benlik algılarının ve mesleklerini nasıl anlamlandırdıklarının merak edilen konulardan biri olduğu vurgulanmıştır (Bayar \& Bayar, 2012: 29). Çalışma, araştırma görevlilerinin çalışma hayatında yaşadıkları deneyimleri ve bu deneyimlerin onlar için ifade ettiği anlamı, mesleğe yönelik algılarını ve karşılaştıkları sorunlarını ortaya koyması açısından önemlidir. Araştırma görevlilerinin mesleklerini nasıl anlamlandırdıklarını ortaya koymada en etkili araştırma deseni fenomenolojik araştırmadır. Bu araştırma deseninin odak noktasını kişilerin belirli bir yaşam deneyimine yükledikleri anlamı onların bakış açısıyla ortaya koymak 
oluşturur. Günümüze kadar yapılan çalışmalarda araştırma görevlilerinin mesleklerini nasıl anlamlandırdıkları fenomenolojik araştırma deseni ile henüz incelenmemiştir. Literatürdeki eksikliği gidermeyi amaçlayan bu çalışmada, eğitim fakültesinde görev yapan araştırma görevlilerinin yaşantı ve deneyimlerine dayalı olarak araştırma görevliliğinin ne anlama geldiği incelenmiştir. Çalışmada, 'Eğitim fakültesinde görev yapan araştırma görevlilerine göre araştırma görevlisi olmanın doğası ve anlamı nedir?' sorusuna cevap aranmıştır. Araştırma sorusu birbiriyle ilişkili iki alt sorudan oluşmaktadır.

1. Eğitim fakültesindeki araştırma görevlilerine göre 'arașttrma görevlisi' olma deneyiminin anlamı nedir?

2. Eğitim fakültesinde araștırma görevlisi olma deneyiminin özü ve yapısı nedir?

\section{Yöntem}

\section{Araştırma modeli}

Araştırmanın amacı ve soruları, hangi araştırma deseninin kullanılması gerektiğini belirleyen en önemli faktörlerdendir. Bu nedenle, çalışmanın amacına ve sorularına uygun olan nitel araştırma geleneklerinden fenomenolojik çalışma deseni kullanılmıştır. Fenomenolojik araştırma, günlük hayatta farkında olduğumuz fakat derinlemesine ve ayrıntılı bir anlayışa sahip olmadığımız olgulara odaklanarak (Yıldırım ve Simsek, 2006:72), tecrübelerimizi ve kendi dünyamızdaki bu tecrübelere yüklediğimiz anlamı ortaya çıkarmayı amaçlamaktadır (Titchen ve Hobson, 2005: 123). Fenomenolojik araştırmalar yorumlayıcı, varoluşçu ve transandantal olmak üzere üç gruba ayrılmaktadır. Bu çalışmada, Edmund Husserl'in öncülük ettiği transandantal fenomenolojiyi araştırma metodu olarak geliştirmiş olan A. Giorgìnin 'betimleyici fenomenolojik araştırma' deseni kullanılmıştır (Giorgi, 2009). Bu araştırma deseni insanların deneyimlerinde ve deneyimlerine yükledikleri anlamlarda ortak olan temel özellikler veya deneyimin özleri ve yapısı açığa çıkarılmaya çalışılır (Denscombe, 2007).

\section{Örneklem (Katılımcılar)}

Araştırmanın katılımcılarını, eğitim fakültesinde çalışan 10 araştırma görevlisi oluşturmaktadır. Araştırma görevlilerinin seçilmesinde amaçlı örneklem yaklaşımı kullanılmıştır. Bu çalışmada her araştırma görevlisi görüşmeyi kabul etmediği için ulaşılabilirlik de dikkate alınarak görüşmeyi kabul eden araştırma görevlileri katılımcılar olarak seçilmiştir. Bu kapsamda 4 erkek 6 kadın olmak üzere 10 araştırma görevlisi çalışmaya katılmıştır. Her katılımcıya araştırmanın amacı ve konusuna ilişkin bilgi verilmiştir. Görüşmeyi kabul eden katılımcılar ile karşılıklı olarak gönüllü katılım formları imzalanmıştır. Araştırma bulgularının sunumunda katılımcıların korunması ve kimliklerinin gizlenmesi amacıyla her bir katılımcıya Katılımcı 1-Katılımcı 10 arasında değişen rumuzlar verilmiştir (Tablo 1). 
Tablo I

Katilımcilar

\begin{tabular}{|l|l|l|l|}
\hline Katılımcılar & Cinsiyet & Yaş & Bölüm \\
\hline Katılımc1 1 & Kadın & 34 & İlköğretim Bölümü \\
\hline Katılımc1 2 & Erkek & 26 & Eğitim Bilimleri Bölümü \\
\hline Katılımc1 3 & Kadın & 33 & İlköğretim Bölümü \\
\hline Katılımc1 4 & Kadın & 29 & Eğitim Bilimleri Bölümü \\
\hline Katılımc1 5 & Kadın & 28 & Eğitim Bilimleri Bölümü \\
\hline Katılımc1 6 & Erkek & 27 & Ö̈ Sosyal Alanlar \\
\hline Katılımc1 7 & Kadın & 32 & Türkçe Eğitimi Bölümü \\
\hline Katı̈lımc1 8 & Kadın & 28 & Güzel Sanatlar Ĕ̆itimi Bölümü \\
\hline Katıllıc1 9 & Erkek & 37 & İlköğretim Bölümü \\
\hline Katılımc1 10 & Erkek & 28 & İlköğretim Bölümü \\
\hline
\end{tabular}

\section{Verilerin toplanması ve analizi}

$\mathrm{Bu}$ çalışmada verilerin toplanmasında yarı yapılandırılmış görüşme tekniği kullanılmıştır. Görüşmede, araştırma görevlisi olmanın anlamını ortaya çıkarmaya yönelik açık uçlu sorular sorulmuştur. Katılımcıların verdikleri cevaplara göre sonda soruları da sorulmuştur. Yapılan görüşmeler katılımcılardan izin alınarak ses kaydına alınmıştır.

Fenomenolojik araştırmada incelenen fenomene ilişkin katılımcıların deneyimlerinin özüne ulaşmak hedeflenmektedir. Bu nedenle, fenomenolojik çalışmanın diğer nitel araştırma desenlerinden farklı, kendine özgü bir analiz süreci vardır. Bu çalışmada, araştırma görevlisi olmanın yapısını ve özünü açığa çıkarmak için önce araştırma verilerini oluşturan mülakat ses kayıtları yazıya aktarılarak analize hazır hale getirilmiştir. Bu teknik işlemden sonra her bir görüşme metni bütüncül bir bakış açısı edinebilmek için okunmuştur. Daha sonra görüşme metinleri analiz edilerek araştırma görevlilerinin deneyimlerinin yapısına ulaşılmaya çalışılmıştır. Analiz işlemi yapılırken şu dört süreç izlenmiştir. Bunlar, 'parantezleme' (araştırmacının üzerinde çalışılan fenomenle ilgili tüm bilgi, düşünce, tutum, değer ve ön yargılarını analiz süresince askıya alması), 'fenomenolojik redüksiyon' (mülakat metinlerinde yer alan deneyimle ilgili temel özellikleri veya anlam birimlerini belirleme), 'imgesel çeşitleme' (anlam birimlerinden yola çıkarak fenomenin yapısal temalarını ortaya çıkarma) ve 'anlam ve özlerin sentezlemesidir (Giorgi, 2009). Görüşme metinleri okunurken araştırmacıların araştırma görevlilerinin mesleki deneyimlerine ilişkin bilgi, düşünce, ön yargı ve değerlerinin mümkün olduğunca verilerin analizini etkilememesine gayret edilmiştir. Fenomenolojik redüksiyon sürecinde araştırma görevlilerinin deneyimlerini betimlemek için kullandıkları ifadeler, içerdikleri anlamlara ve bu anlamlar arasındaki nüanslara göre farklı birimlere bölünmüştür. İmgesel çeşitleme yapılırken araştırma görevlilerinin deneyimlerinde saklı olan anlamlar ortaya çıkarılmıştır. Bu süreç sonucunda her bir katılımcının kullandığg ifadeler esas alınarak anlam üniteleri ve yapısal profil oluşturulmuştur. Analizin son aşamasında ise katılımcıların profillerindeki anlam üniteleri arasındaki ortak noktalar ve yapısal 
temalar tespit edilerek araştırma görevlisi olma fenomeninin değişmeyen özleri ve yapısı açı̆̆a çıkarılmıştır.

\section{Bulgular}

\section{Eğitim fakültesinde araştırma görevlisi olmanın anlamı}

Araştırma verilerinin analizi sonucunda, çalışmaya katılan araştırma görevlilerinin görüşleri doğrultusunda eğitim fakültesinde araştırma görevlisi olma fenomeninin yapısını ve özünü şu bileşenlerin oluşturduğu belirlenmiştir:

1. İstismar edilme: sekreterlik ve angarya işler yapma: Araştırma görevlileri, görev tanımlarında yer almayan ve akademik çalışma kapsamında değerlendirilemeyecek sekreterlik işleri, angarya işleri ve hocalarının işlerini yapmak zorunda kalmaktadırlar. Araştırma görevlilerinin kendi başlarına yaptıklarıçalışmalara hiç emekleri olmadıkları halde bölümlerindeki bazı hocalar ortak olmaktadırlar. Bu olumsuz deneyimler araştırma görevlilerinde kullanılma ve istismar edilme algısını doğurmaktadır.

2. Akademik baskıyla karşılaşma: Araştırma görevlileri akademik çalışmalarında yeterince özgürce hareket edememektedirler.

3. Ekonomik sıkıntılarla yüzleşme: Araştırma görevlileri, ekonomik olarak kendi ihtiyaçlarını karşılama ve akademik çalışmalar yapma konusunda zorluklarla karşılaşmaktadırlar.

4. Motivasyon kaybı yaşama: İstismar edilme, akademik ve ekonomik baskı altında yaşama gibi deneyimler araştırma görevlilerinin mesleğe yönelik tutumlarını ve motivasyonlarını olumsuz yönde etkilemektedir.

5. Akademik kariyer yapma ve kimlik kazanma: Araştırma görevliliği sürecinde edinilen tecrübeler, araştırma görevlilerinin akademik kariyere adım atma ve kimlik kazanma sürecinde önemli bir rol oynamaktadır.

6. Akademik gelişim sağlama \& entelektüel doyum: Araştırma görevlilerinin araştırma görevliliğine başladıkları zamandaki akademik yeterlilikleri ile mevcut akademik durumları arasında önemli farklılıklar bulunmaktadır. Araştırma görevliliği deneyimi, araştırma görevlilerinin kendilerini akademik olarak geliştirmelerini sağlamaktadır.

Çalışmaya katılan araştırma görevlileri, evrak ve angarya işleri yapma, hocaların yerine derse girme gibi işlerle uğraşmanın kendilerini rahatsız ettiğini ve kullanıldıklarını düşündüklerini belirtmişlerdir. Araştırma görevlileri hem kendi kişisel hayatlarında hem de akademik çalışmalarda ekonomik sorunlarla karşılaştıklarını, bu durumun yaptıkları akademik çalışmaları engellediğine dikkat çekmişlerdir. Katılımcılar, gerek iş hayatında gerekse ekonomik anlamda 
yaşadıkları sorunların mesleğe ilk başladıklarındaki motivasyonlarında azalmaya yol açtığını belirtmişlerdir. Araştırma görevlilerinin bu süreç içerisinde yaşadıkları deneyimlerin ileride nasıl bir akademisyen veya öğretim üyesi olacaklarını etkilediği ve akademik kimlik kazanmalarında önemli bir faktör olduğu belirlenmiştir. Bilimsel çalışma yapmanın araştırma görevlilerine entelektüel doyum sağladığı ve onların akademik gelişimlerine katkıda bulunduğu tespit edilmiştir. Aşağıdaki paragraflarda araştırma görevlisi olma deneyiminin yapısını oluşturan bileşenler detaylı olarak açılanarak betimlenmiştir.

\section{Istismar edilme: sekreterlik ve angarya işler yapma}

Araştırma görevlilerinin yazışmaları takip etme ve evraklarla uğraşma gibi sekreterlik ve angarya işlerle meşgul edildikleri, hocaların özel işlerini yaptıkları, onların yerine derslere girdikleri, bir akademisyenin yapmayacağı işleri yapmaya zorlandıkları, onların ifadesiyle "hamallık ve $\imath$ vir-zivır" işler yaptıkları tespit edilmiştir. Araştırma görevlileri, bazı hocaların emekleri ve katkıları olmadığı kendi yaptıkları bilimsel çalısmalara isimlerini yazdırdıklarını ifade etmişlerdir. Araştırma görevlilerinin görev tanımlarında olmadığı halde akademik olmayan işler yapmaya zorlanmaları ve yaptıkları bilimsel çalışmalara hiçbir emeği geçmemiş olan hocaların ortak yazar olmaları kendilerinin istismar edildiğini göstermektedir. Elde edilen bu bulgular katılımcıların mülakat metinlerinden alınmış doğrudan alıntılarla aşağıda detaylı olarak betimlenecektir.

\section{Sekreterlik işleri yapma}

Katılımcıların araştırma görevliliği deneyimlerinin önemli bir kısmını bölümde sekreterlik işleri yapmalarının oluşturduğu tespit edilmiştir. Katılımcılar, mesailerinin büyük bir kısmını sekreter gibi resmi yazışmalar yaparak ve evrak işlerini takip ederek geçirdiklerini belirtmişlerdir. Örneğin Katılımcı 2, bölümdeki sekreterlik işleriyle ilgili olarak "Şu yazı yazılacak, hadi sekreterliğe geç, sekretaryanın işlerini yap" diyerek yalın ve özlü bir şekilde yaşadığı deneyimi dile getirmiştir. Katılımc1 4 "Bölümle ilgili olarak yaptı̆̆ımız bu idari işlerin vesaire hayatımızda çok büyük bir yeri var maalesef" sözleriyle zamanının büyük bir kısmını sekreterlik işlerine ayırmak zorunda kaldığını ifade etmiştir. Bu deneyimini “maalesef” kelimesi ile ifade etmesi kendisinin bu durumdan rahatsız olduğunu açık bir şekilde ortaya koymaktadır. Katılımcı 6 da araştırma görevlisi olarak sekreterlik işleri yapmaya mecbur edilmelerinden dolayı yaşadıkları sıkıntıya şu sözlerle dikkat çekmiştir: "Bürokratik olarak yazışmalar konusunda araştırma görevlilerinin mesaileri yoğun. Вu büyük bir sıkıntı. Bu konuda önlem alınmal, yani biraz daha araștırma görevlileri kendi işlerine daha fazla ağırlık vermeli, ben bunu yaşıyorum." Katılımc1 3 de benzer bir durum yaşadığını, zamanının çoğunluğunu daha çok sekreterlik işleri yaparak geçirdiğini "Benim işim sadece bölümün idari işleri, bölümün sekretarya işleri, işte ana bilim dalının" sözleriyle ifade etmiştir. Katılımcı 1, sadece kendisinin değil diğer araştırma görevlilerinin de sekreterlik işleri yapmak zorunda kaldıklarını şu cümlelerle ifade etmiştir:

Hocaların çok yoğun olmasından ya da hocaların tercihi olmasından mı bilemiyorum, ama burada çok daha yoğun olarak işlerden sorumlu olduğumuzu, öğrenci problemlerinden, işte 
sınav programlarını birçok yerde araştırma görevlileri yapar burada yazışmalardan falan. Ben yazışmaların yapılması konusunda ilk defa burada bu kadar araştırma görevlisinin sürecin içine dahil olduğunu gördüm.”

Katılımcı 1'in bu sözleri araştırma görevlisi olarak neden sekreterlik işleri yaptıklarını sorguladığını göstermektedir. Katılımcı 5, "Sekreterlik işlerinden tutun da akademik derslerin takibine kadar, işte kongre, dergi vesaire her iş araştırma görevlilerinin elinden bir şekilde geçiyor" diyerek bir araştırma görevlisi olarak uygulamada yaptıkları işlerin sınırlarının tam olarak belli olmadığından yakınmıştır. Katılımcı 10, sekreterlik işleri yapma konusunda yaşadığı sorunu şu şekilde dile getirmiştir: “Araştırma görevlilerinin en büyük sıkıntısı, bu ortak bir sıkıntıdır, mesela bölümde bir evrak yazılacaksa evrakı siz yazarsınız. Alanla ilgili olmadığı için bölüm sekreteri doğrudan o evrakı yazamayacaktır ki, yazması gerekiyor normalde." Katılımc1 8, bir sekreterden de çok evrak işleri yaptığını, "Sekreter ne yapıyorsa, yani sekreterden daha çok görev yaptı̆̆ımız kesin. Yani sekreterlerin bazıları sadece mesai doldurup gidiyor" sözleriyle ifade etmiş ve karşılaştığı bu durumun sebebi hakkında şu açıklamayı yapmıştır: "Şartlar mı diyeyim, yoksa nasıl anlatabilirim bilmiyorum, ama farklı işlerle bize yükleniyorlar ve bunu yapmak zorunda kaliyoruz. Bir sekreterin yapması gerektiği işleri çoğu zaman biz yapıyoruz hani bölüm başkanının talimatları gereği diyeyim.” Bu ifadeler, diğer katılımcılar gibi Katılımcı 8’in de sekreterlik işleri yapmak zorunda olmasını sorguladığını ama bunun nedenleri konusunda açıklama yapmaktan çekindiği ortaya koymaktadır. Araştırma görevlilerinin yaşadıkları deneyimlere dayalı olarak yaptıkları bu tespitler, sorunun kökeninde daha çok idari yetkiyi elinde bulunan öğretim elemanlarının olduğunu göstermektedir. Araştırma görevlilerinin sekreterlik işleri yapmak zorunda kalmaları akademik çalışmalara yeterince zaman ayıramamalarına sebep olmakta, bu durumda akademik gelişimleri engellenmektedir.

\section{Angarya işler yapma}

Katılımcılar, bölümde sekreter rolü üstlenme gibi akademik olmayan işler yapmanın yanı sıra başka angarya işler de yaptıklarını belirtmişlerdir. Katılımcı 2, bölümde yaptı̆̆ 1 angarya işleri şu şekilde örneklendirmiştir: "Örneğin, bölümde bir tane masa şuradan şuraya taşınacaktır. İste araştırma görevlisi arkadaşlar, buyurun, şunları şuraya alalım. Mesela bu bir angarya iş, vay efendim işte resmi yazının fotokopisi çekilecek hadi birini ver, çektiri ver." Katılımcı 2, angarya işlerle uğraşmasını araştırma görevliliğine değer verilmemesi olarak değerlendirdiğini, "Yani araştırma görevlisi angarya işleri yapar doktorasını bitirene kadar, pek bir önemi yoktur" sözleriyle dile getirmiştir. Bu durumun kendisini çok rahatsı ettiğini ise "Bu angarya işlerden dolayı şikâyetimiz çok fazla. Yani angarya işlerin verilmesi” diyerek belirtmiştir. Katılımcı 1, hocaların şahsi işlerini yapmak zorunda kalmalarından duyduğu rahatsızlığ ve bu durumun verdiği istismar edilmişlik hissini şu şekilde dile getirmiştir:

Hani hocalar en basit yapabilecekleri işleri bile aslında kendi bireysel işi, araştırma görevlisine sen bu işi yapar mısın diyebiliyorlar. Bireysel anlamda düşündüklerinde aslında onların işi, yapılmaması gerekiyor ama araştırma görevlisi de buna çoğu zaman hayır 
hocam ben yapmam diyemiyor... Başkasının yapması gerekli olan bir şeyi ben yapıyorsam ve o sorun çäzülüyorsa orda rahatsızlk hissediyorum. Kendimi kullanılmış hissediyorum birazcık açıkçası.

Katılımcı 4, "Benden daha kıdemli olan hocalarım için özellikle sadece onların küçük kişisel ve çok teknik işleri ile meşgul olmuşsam... Belki daha da kötüsü önemsediğgim şeyleri yapma konusunda engellenmişsem... İște o zaman kötü hissettiriyorum, yani yanlış bir yerdeyim, engelleniyorum sonuçta" sözleriyle hocaların şahsi işlerini yapmak zorunda kalmanın kendisinde yaşattığ 1 olumsuz duyguyu dile getirmiştir. Öğretmenlik mesleğinden ayrılıp araştırma görevliliğine dikey geçiş yapmış olan Katılımcı 3, araştırma görevlisi olarak yaptı̆̆ı angarya işleri şöyle özetlemiştir:

Milli Eğitim'den istifa ettim ve okula geldim. Sonra bir baktım ki, Word'de tablo düzeltme, program yapma, işte sınavda gözetmenlik yapma, ana bilim dalının diğer işlerini yapma, harita odası düzeltme. Tabi ki bunlar da yapilabilir... Çok fazla hem idari hem de akademik olmayan işlerle meşgul buldum kendimi.

Aynı kat1lımc1, "Ya ben burada neyim? diye kendimi sorgularken buldum. Niye böyle yapıyorlar? diye söylenirken buldum" diyerek akademik olmayan işleri yapmak zorunda kalmasından dolayı araştırma görevliliğini sorguladığını açıkça beyan etmiştir. Katılımcı 8, angarya işleri hamallık olarak değerlendirdiğini şöyle ifade etmiştir: "Mesela, etkinlikler oluyor sandalye taşı. İşte işin hamallk boyutu ne kadar varsa biniyor çoğu zaman." Katılımcı 8, angarya işler yapmanın akademik çalışmalar üzerine yoğunlaşmalarını nasıl engellediğini de açıklamıştır:

Tam bir şeye konsantre olmuşken telefon çalı, hocanın biri çağırıyor, bölüm başkanı çağırıyor. Başka gereksiz işlerde bizi uğraştırması yine bölük pörçük bir ortam yaratıyor. Mesela, "Bir temizlik görevlisine ulaşamıyorum. Ona bakıp haber ver, bana gelsin... Kantine arıyorum. Sürekli meşgul. Kantine git. Kapatsınlar telefonu, arayacağım... Odaya hocanın biri geliyor, Şu kişinin telefonu var mı? Benim unvanım değişti, bunu kim yapıyor? Bir söyler misin" diyor. Ben nerden bileyim?” Onun haricinde böyle işler yani. En gereksizi bunlar. Daha örnek vermeme gerek yok bence. Araștırma görevliliği sürecinde hocaların görevlerini de yerine getireceğiz ama asıl amacımız bizim burada doktora öğrencisi olmamiz da unutulmamal.

Katılımc1 9, bölümdeki hocaların özel işlerini araşıırma görevlilerine yaptırdığını, "Yani kitap taşımaktan, işte arabamdan şunu getir, şu ilacı yazdır, falan filan” sözleriyle vurguladıktan sonra hocaların kendilerini değersiz gördükleri için kendilerine böyle davrandıklarını şu metaforik ifadelerle açıklamıştır: "Biz yolunacak kazız. Ne kadar evrak işi, ne kadar angarya iş, ne kadar kendisinin vakit ayırmaya tenezzül etmediği ıvır zıvır işler varsa onlar araştırma görevlisi halleder." Katılımc1 9, "Herkese tamam demek, bir araştırma görevlisinin en asli görevi. Her hocasına tamam diyecek. Hayır deme hakkı yok" diyerek hocalardan gelen kişisel talepleri reddetme cesaretine 
sahip olamadıklarını söylemiştir. Katılımcı 9, araştırma görevlisi olarak hocalar tarafından istismar edilmesini ve bu durum karşısında kendinde gelişen öğrenilmiş çaresizliği şu metaforik ifadelerle betimlemeye çalışmıştır:

Araştırma görevliliği bana göre şu: Ben bir eşeğim, sırtımda semer var, üniversiteye girdiğim zaman o semere kimin bindiğinin hiçbir önemi yok. Mutlaka birisi biniyor. Ama o şey şu: Bende semer var. Biri binecek. Onu kabullenmem gerekti ilk önce. Onu kabullendim. Sonra dedim ki: Birisi binecek. Kimin bindiği çok önemli değil ama iki kişi binmesin, üç kişi binmesin. Çünkü gücünüz bir süre sonra, birilerini taşımaya yetmiyor.

Araştırma görevlilerinin sadece hocaların akademik olmayan günlük şahsi işlerini değil, akademik görevlerini de onların yerine yaptıklarını belirlenmiştir. Araştırma görevlilerinin derse girmeleri kanun ve yönetmeliklere göre yasaktır. Fakat katılımcılardan hocaların yerine dönemlik ders yürüttüklerini ifade edenler dahi olmuştur. Örneğin Katılımcı 10, bu konuya ilişkin deneyimlerini şöyle ifade etmiştir: "Derslere giriyoruz, mesela hizmet uygulamaları dersi, staj uygulaması dersi tarzında, öğretmenlik uygulaması dersi tarzında derslere giriyoruz." Katılımcı 7’de ders hocaların yerine derse girmek zorunda kaldığını şu şekilde ifade etmiştir:

Derslere girdim ben. Bir dönem özellikle eskiden çok, burada değil de, iki üniversitede derslere girdim. Birinci üniversitemde çok fazla ders vardı. Benim haftada 18-20 saat gibi. Yani orda zaten çalışmalarına çok sıkı. Hani bir araştırma görevlisinden ziyade, öğretim görevliliği fonksiyonu ön planda. Dersler anlatıyorsunuz."

Katılımc1 9, bölümde dersine gelmeyen her hocanın yerine derse girdiğini, "Falan hoca gelmedi, sen onun yerine derse gir. Başka bir hoca gelmedi, onun yerine derse sen gir... Bir de dönemlik yürüttüğ̈̈nüz dersler var" ifadesiyle dile getirmiş, bu emri vakilerin acı bir tecrübe olduğunu ve kabullenemediğini şöyle açıklamıştır: "Elbette farklı işler yapmak, üniversitenin işleyişini görmek önemli ama her bir boşlukta sizin orayı doldurabilecek joker olarak görülmeniz bana göre acı... Siz bütün derslerin jokeri olamazsınız. Böyle bir şey yok.”

Katılımcı 10, yaşadığ 1 farklı bir istismar deneyimine dikkat çekerek yaptığı bilimsel çalışmalara hiç katkısı olmadığı halde bazı hocaların ortak olduklarını, bazılarının da özellikle bölüm başkanlarının, tek yazarlı çalışma yapmalarını engellediklerini “...yazılmamış bir kanun tarzında bölüm hocası o çalışmada yer almalı" sözleriyle ifade etmiştir. Katılımcı 9 da benzer bir istismarla karşılaştığını "Hadi makale yazalım çocuklar. Siz yazın, ben bakarım. Götürüp koyuyorsunuz. Hadi bakın. Sen yazmışsan olmuştur” ifadeleri ile dile getirmiş, bazı hocaların çalışmayı araştırma görevlilerine yaptırdığını, hatta inceleme gereği bile duymadan bütün sorumluluğu onlara bıraktığına dikkat çekmiştir. Katılımcı 9, bu istismara karşı tepkisini ve kendinde bıraktığı etkiyi "O zaman sana ne ihtiyaç var. Ben yazıyorum oluyor, öğrenme sürecindeki biri olarak. Sen niye ordasın? Araştırma görevliliği insanın kişiliğini yıpratan bir meslek bana göre” sözleriyle ifade etmiştir. 
Katılımcıların bu ifadelerinden anlaşıldığı üzere; araştırma görevlilerinin sekreter gibi çalışmaları, hocaların özel işlerini yapmaları, bir hizmetli gibi çalıştırılarak çeşitli angarya işler yapmaya zorlanmaları, akademik çalışmalarına katkıları olmadığı halde başka hocaların çalışmalarına ortak olmaları onlarda istismar edilme hissini doğurmaktadır. Bu durum araştırma görevlilerini psikolojik açıdan oldukça rahatsız etmekte, bilimsel çalışmalar yapmaya yeterince zaman ayırmalarını ve kendilerini akademik açıdan geliştirmelerini engellemektedir.

\section{Akademik baskıyla karşılaşma}

Çalışmaya katılan araştırma görevlileri, bölümlerindeki hocaların kendilerine akademik müdahale, baskı ve sınırlandırma yaptıklarını da belirtmişlerdir. Katılımcılar, yapacakları çalışmalar için önceden hocalarından izin almaları gerektiğini, akademik olarak özgür hareket edemediklerini, belli bir kalıbın içerisine sokulduklarını ve sınırlamalar yaşadıklarını ifade etmişlerdir.

Katılımcı 10, "Makale yazmamız gerekiyor. Kendi başınıza çok özgürce hareket edemiyorsunuz. Hocanızın ilgi alanına göre çalışmanız gerekiyor, çokta özgür olamıyorsunuz. Kendi başınıza bir çalışma yapamıyorsunuz, icazet almanız gerekiyor bölüm başkanınızdan" diyerek akademik çalışma yapma konusunda özgürce hareket edemediğini, bölüm başkanının baskısı ile karşılaştığını belirtmiştir. Katılımcı 10, hocasının isteği üzerine kendi istediği bir alanda çalışma yapmaktan vazgeçmek zorunda kaldığını "Siz istiyorsunuz, hocanız istemediği için vazgeçebiliyorsunuz" sözleriyle dile getirmiştir. Katılımc1 4, "Kendi merak ettiklerimin peşinden gidebilmek için araştırma görevlisi” oldum demiştir ama isteklerini gerçekleştirme konusunda engelleme ile karşılaştığını ve baskı gördüğünü "bazen size bu kadarda merak etme, bu kadarda kendi doğrularınla hareket etme" sözleriyle ifade etmiştir. Katılımcı 4, yaşadığı akademik müdahale, baskı ve emr-i vakileri ve bu deneyimler karşısındaki his, düşünce ve değerlendirmelerini detaylı olarak şöyle açılamıştır:

Bir kalıbın içerisine sokuyorlar, bir hiyerarşinin içerisine sokuyorlar, neyi öğrenmeniz gerektiğini başkaları tanımlıyor, neyi nasıl yapmanız gerektiğini de başkaları tanımlıyor ve bunu buyuruyorlar... Genellikle öğrenciler tarafindan yapılan bazı çalışmalar var, veyahut hocalar tarafindan yapılan fakat çok özensizce, özen gösterilmeksizin, üzerinde düşünülmeksizin, öylesine yapılmış. Size: 'Bu çalışmayı al düzelt ve adam et' deyip sunuyorlar. Müthiş bir savaş içerisine giriyorsunuz.... Araştırma görevliliğinin bence en anlamsız ve saçma tarafi bu, belki saçmadan daha sert kelimelerde kullanılabilir de ben bilemiyorum, bu kelimenin ne olduğunu.

Katılımcı 9, hocaların danışmanlık yapmayı kabul ettikleri öğrencilerin kendilerine minnet duymasını beklediklerini, bunun ise araştırma görevlileri için olumsuz neticeler doğurduğunu şöyle ifade etmiştir: "Böyle sürekli minnet duymanızı istedikleri için, bu da bilimsel anlamda özgür bir düşünceye sahip olmamızı engelliyor.” Katılımc1 9, buna ilaveten çalışma alanı konusunda da sorunlar yaşandığını "Doktor oluncaya kadar alanda sözü geçen hocalarınızın hiçbir tanesinin kendine belirlediği uzmanlık alanına girişemiyorsunuz” sözleriyle ifade etmiştir. Katılımc1 3, 
görüşüne başvurulmaksızın kendisinden habersiz olarak tez danışmanının belirlendiğini belirtmiştir: "Tez danışmanım ve tez izleme jürim benden habersiz olarak atandı. Buna itiraz ettim. Çok iyi karşılanmadığını biliyorum, hissediyorum ama buna karşı çıkmak zorundaydım.” $\mathrm{Bu}$ ifadeler, araştırma görevlilerinin çalışma alanında, çalışma konusu seçiminde ve kiminle çalışmaları gerektiği konusunda özgür olamadıklarını, akademik müdahale ve baskıyla karşılaştıklarını ortaya koymaktadır.

\section{Ekonomik sıkıntılarla yüzleşme}

Araştırma görevlilerinin hem kişisel hayatlarında hem de akademik çalışmalarında ekonomik sorunlarla karşılaştıkları tespit edilmiştir. Katılımcılar, araştırma görevlisi olarak çalışma yaparken ekonomik yetersizlikten dolayı sınırlama yaşadıklarını belirtmişlerdir. Örneğin, Katılımc1 5, "Kongre için kendi giderlerimi kendi cebimden harcadım. Bu bir kere oluyor, iki kere oluyor, üçüncüde, bizim zaten aldığımız maaş belli... üçüncüde gitmiyorsun kongreye ve akademik gelişimin bir yerde durmaya başlıyor” diyerek ekonomik yetersizliğin çalışmalarına yansıdığını belirtmiştir. Katılımc1 3, "İlginç bir yönü de bu mesleğin, size diyor ki 'daha çok araştırma geliştirme yapın diye istihdam ediyorum' ama üç kuruş kongre desteği almak için canımız çıkıyor” ifadeleri ile araştırma yapmaları için öngörülen desteği almadaki yaşadığı zorluğa dikkat çekmiştir. Katılımcı, “ ̧̈̈ç kuruş kongre desteğ $i$ ” ifadesi ile verilen desteğin azlığını vurgulamıştır. Katılımcı 7, yaptığı araştırmaların maddi yük getirdiğini, çalışmalar için yapılan masrafların kendi cebinden çıktığını belirtmiştir: "En çok sıkıntı çektiğim nokta yaptığımız araştırmaların maddi anlamda güçlüklerle sınırlanmasıdır. Dediğim gibi il dışına çıktığınızda çok külfetli oluyor. Bunu da cebinizden karşılamak zorundasınız. Bizim aldığımız maaşlar belli. Gelirimiz belli, giderimiz belli.” Katılımcı 7 da, ekonomik desteğin yetersiz olmasından dolayı bilimsel toplantılara sınırlı düzeyde katıldığını şu sözlerle açıklamıştır: "Mesela, bazı üniversiteler sadece bir tane bildiriyi kabul ediyor. O da doktora öğrencisi olarak gittiğiniz durumda karşılıyor. Birden fazla bildiriye katılamıyorum bir tane hakkım kalmışona katılıyorum. O da sınırlıyor ister istemez çalışmalarımızı."

Katılımcı 9 da benzer ekonomik sıkıntılar yaşadığını, bilimsel çalışmalar için maddi destek alamadıklarını "Bilimsel toplantıları gidiyoruz. Yolluk yok, yevmiye yok” sözleriyle dile getirmiştir. Bazı araştırma görevlileri, akademik çalışmalarda yaşadığı ekonomik yetersizliğin yanında, aldıkları maaşın yetersizliğini ve ek iş yapmak zorunda kaldıklarını ifade etmişlerdir. Örneğin Katılımcı 9, "Araştırma görevlisinin parası az ne yazık ki...Ek iş yapmak zorunda kalıyorsunuz.... İște dershanelerdir, hatta arkadaşlardan biliyorum para kazanmak için stant hostesliği yapanlar bile var" diyerek maaştaki yetersizlikten dolayı ek iş yapmak zorunda kaldığını ifade etmiştir. Katılımcı ek iş yapmanın toplumdaki akademisyen algısını da etkilediğini "Ek iş yapmanız piyasadaki bilim insanı algısını aşă̆ılara çekiyor” sözleri ile belirtmiştir. Katılımcı 10, araştırma görevlileri tarafında ödeneklerin yetersizliğinin yanında sağlanan kısıtlı desteğinde kongre bittikten sonra yapıldığını şu şekilde ifade etmiştir: "Yalnız ödenek önce verilmiyor kongreye gidip sunumu yaptıktan sonra ödenekler veriliyor. O noktada sıkıntılar yaşıyoruz, ödenek bulma noktasında sıkıntılar yaşıyoruz." Ekonomik zorluklara ve maddi yetersizliklere ilişkin katılımcılar tarafından belirtilen diğer görüşler aşağıda verilmiştir: 
Katılımc1 3: “Türkiyede araştırma görevlisi olmanın şöyle bir sılkıntısı var. Gerçekten maddi olarak yetemiyorsunuz.”

Katılımcı 10: “Maaş konusuna girersek, hayal kırıklı̆̆ı yaşadı̆̆ımı söyleyebilirim.”

Katılımc1 8: "Genel olarak zaten akademik personele maaşlar az... Ekonomik anlamında sıkıntıları var. Özellikle, büyükşehirlerde hani araştırma görevlisi olarak özellikle bekarsanız ve tek başınıza yaşıyorsanız zor gerçekten yeterli değil.”

Katılımc1 6: "Akademik hayatımızda en fazla masraf yaptığımız dönemi yüksek lisans doktora dönemi... Ekonomik olarak öncelikle büyük şshirde yaşadığımız için büyük dağın büyük kışı oluyor. Ekonomik standartlarında iyileştirme yapılmadığı için sınav görevlerinde daha çok görev alıyoruz. ...Ekonomik olarak buna ihtiyacım var. Ona da gitmek zorundayım."

Katılımcı 5: "Eskiden şöyle bir şey varmış akademisyenleri maaşları ve prestijleri oldukça yüksekmiş ama bence şu anda hiç öyle bir şey söz konusu değil."

Katılımcıların ifadelerinden de anlaşılacağı üzere, araştırma görevlileri hem maaş hem de araştırama yapma konusunda ekonomik zorluklar yaşamaktadırlar.

\section{Motivasyon kaybı yaşama}

Çalışmaya katılan araştırma görevlileri, akademik gelişim veya araştırmaya yönelik enerji ve isteklerinde araştırma görevliliğine başladıkları ilk zamanlara göre azalma olduğunu belirtmişlerdir. Araştırma görevlileri motivasyon kaybına sebep olan faktörleri akademik dışı işlerle uğraşma, akademik özgürlüğe sahip olamama ve çalışmalara ekonomik desteğin yetersizliği olarak ifade etmişlerdir. Katılımcı 4, araştırma görevliliği sürecinde akademik dışı işlerle uğraşmalarından dolayı rahatsız olduğunu, henüz motivasyonu kaybetmediğini belirtmekle birlikte iş arkadaşlarında tanık olduğu durumu şu şekilde açıklamıştır: "Ben bunu yaşamadım çok şükür fakat yaşayanlar var. Mademki biz bu kadar değersiz işlerle uğraşıyoruz ve bizden sadece beklenen budur. Öyleyse daha iyisi için uğraşmaya sebepte yok.” Katılımc1 4, motivasyon kaybına neden olan diğer bir faktörün kendilerine uygulanan akademik baskı olduğunu "Yani onların istediklerini yapalım, onlar belirlesin oyunun kurallarını -bizde işte okuyalım, öğrenelim, araştıralım bunlar çok önemli olmasın- deyip kendi inandıklarından vazgeçen arkadaşlarım var" ifadeleri ile dile getirmiştir. Katılımc1 9, bilimsel olarak yaşadığı değersiz görülmeyi ve bu durumun neden olduğu motivasyon kaybını "Bilimsel bir ortamda sizin ifadenizin, o konu ile ilgili katkınızın, görüşünüzün hiçbir değeri yok” sözleriyle ifade etmiştir. Katılımcı bu nedenden dolayı akademik gelişim ile ilgili problemler yaşadığını şu şekilde belirtmiştir:

Bunun bilim olduğuna da inanmıyorum. Yapılan araştırmaların bilimsel çalı̧̧ma olduğuna inanmıyorum. Çünkü böyle bir tepki gelişti ister istemez. Size böyle bakan insanların yaptıkları çalışmaların değersiz olduğunu düşünmeye başlıyorsunuz ve bu da şöyle bir sonuç doğuruyor: O kadar değersiz bir çalışmayı benim de yapmamın bir anlamı yok. Bu gelişiminize ket vuruyor... Türk bilim dünyasına ya da bilim dünyasına katkı sağlayabileceğimiz ivmeyi tamamen körelten" 
Katılımcı 8 üniversitede çalışmak istemesine rağmen çalışma ortamının akademik gelişime elverişli olmamasından dolayı çalışma azminin ve şevkinin kırıldığını "Çalışma içerisine girmek istiyorum ama üniversitedeki ortam dediğim gibi biraz daha firsat olması gerekiyor. Bunu yapabilmem için hevesimi bunların kırmasına izin vermemek istiyorum aslında ama işte çoğu zamanda kırılabiliyor" sözleriyle ortaya koymuştur. Katılımcı 3, "Telefon çalıyor. Yani, o zaman bütün motivasyon, o gün o iş aksıyor... kırıliyorsunuz ve bunlar engel oluyor aslında sizin yapmak istediğiniz şeylere engel oluyor ” diyerek çalışırken çıkan farklı işlerin motivasyonunu nasıl dağıttığını ve yapmak istediği çalışmayı yapamadığını belirtmiştir. Katılımcı 6 ise "Çünkü şu var sisteme geliyorsunuz ve ister istemez eskiden idealistken çok hayal kuruyorduk. Şimdi gerçeklerle karşılaştı̆̆ımız için biraz hayallerimiz minimum seviyeye iniyor. Biraz daha gerçekler ön plana çıkıyor o yüzden idealistliğimiz azalıyor” sözleri ile araştırma görevliliği sürecinin kendisini idealistlikten uzaklaştırıp motivasyonunu azalttığını söylemiştir.

Araştırma görevlilerinin motivasyon kaybına sebep olan faktörlerden biri olarak da çalışmalara verilen ekonomik desteğin yetersiz olması tespit edilmiştir. Örneğin, Katılımcı 5, mesleğe başladıklarında daha heyecanlı, girişimci ve azimli olduklarını, "Mesela ben eskiden ilk mezun olduğum zaman daha aktiftim daha çok kongrelere giderdim. İşte bir şeyler yazmak için uğraşırdım vesaire" diyerek ifade etmiş fakat bu yolda gerçekleştirmeye çalıştıkları çabaların ekonomik olarak desteklenmemesi sonucu yaşadığı olumsuz durumu şu şekilde açıklamıştır:

Ama artık öyle bir heyecanım yok açıkçası... Aslında biz hepimiz bilim insanı olmak için girdiğimizde idealist başlyoruz. İste Türkiye’yi geliştireceğimizi, bir sürü katkılar yapabileceğimize inanıyoruz. Belki yurt dışında çok iyi bir şekilde temsil edeceğimize inanıyoruz. Ama çok ufacık bir katkı beklediğimizde örneğin kongreye giderken katkı beklediğimizde engelleniyoruz ve burada da ümitsizlik ve çaresizlik yaşamaya başlıyorum. Yani tek başıma gerçekten bu ideal düşüncelerimle bu işe ulaşabilecek miyim? Çokta ütopik gelmeye başlıyor bir süre sonra sizin ideal düşünceleriniz. O yüzden bu deneyimlerim beni ketlemeye başlıyor, ilişkilerimi durduruyor.

Katılımc1 3'de, "Yani, bu süreç ama işte moralimi bozan böyle karşımda ket set olarak gördüğüm şeyler de yani üç kuruş beş kuruş bunların hesabını yapıyoruz. İhtiyacımız var gerçekten” diyerek motivasyonunun azalmasında ekonomik desteğin yetersizliğine dikkat çekmiştir. Katılımcı 8, "Ekonomik olarak daha iyi şartlar görmek bizim de araştırmalarımızı çalışmalarımızı teşvik edecektir” sözleriyle araştırma görevlilerinin çalışmalara ekonomik desteğin yeterli düzeyde olmadığını bu durumun da çalışma azimlerine olumsuz yönde yansıdığına işaret etmiştir.

\section{Akademik kariyer yapma ve kimlik kazanma}

Akademik kariyerin ilk adımı olan araştırma görevliliğinin araştırma görevlileri için önemli olduğu belirlenmiştir. Katılımcıların araştırma görevliliğinin akademik gelişime uygun bir meslek olduğunu düşünmelerinin akademik kariyere başlamalarında etkili olduğu görülmüştür. Katılımcılar, donanımlı olmak ve araştırma yapmak amacıyla araştırma görevlisi olduklarını 
söylemişlerdir. Örneğin Katılımcı 4, araştırma görevliliğine adım atma sürecini "Iş̧in üretici tarafinda olabileceğim bir işle meşgul olmak istiyordum... Kafamda hep merak ettiğim öğrenmek istediğim bir şeyler var ve bunların çok değerli olduğuna inanıyorum ve bu değerli şeyleri öğrenmenin ilk basamağı da araştırma görevlisi olmaktan geçiyor, en gözde, en kıymetli tarafı bu galiba" sözleriyle açıklamıştır. Katılımcı 4, değerli gördüğü ve merak ettiği konuları öğrenmenin ilk basamağı olarak araştırma görevliliğini gördügünü, bu nedenle araştırma görevliliğine başladığını belirtmiştir. Katılımcılar 9, araştırma görevliliğine başlarken asıl amacının kendini geliştirmek olduğunu "asıl temel başlangıcı, kendimi geliştireyim" diyerek belirtmiş, kendi çalışma alanına akademik açıdan katkıda bulunma isteğinin mesleğe başlamasını etkileyen unsurlardan biri olarak değerlendirmiştir: "Lisans alanıma katkı sağlayabilecek bilimsel bir tarafa yönelmek istedim. Bunun yolu da o zamlar neyden geçiyor? Dediğim gibi: Araştırma görevliliğinden geçiyor." Katılımcı 5, Milli Eğitimde öğretmenlik yaparken kendini geliştiremediğini bu amacını gerçekleştirmek için akademisyenliğe adım attı̆̆ını "kendimi geliştirmek hani daha büyük katkılar sunmak için" sözleriyle ifade etmiştir. Benzer şekilde önceden öğretmenlik tecrübesine sahip olan Katılımcı 7, araştırmaya yönelik ilgisinin öğretmenlik mesleğini yaparken başladığını, "Ben öğretmenlik yapamam dedim ama araştırmaktan da hoşlandiğımı fark ettim... bu şekilde daha çok hayattan memnun olduğumu anlayınca akademisyenliği seçtim" şeklindeki sözleriyle ortaya koymuştur. Katılımcı 2, araştırma görevlisi olma sebeplerinden biri olarak akademisyenliğin "kendini sürekli geliştirebilmesi” için “müsait olması" olmasını göstermiştir. Katılımcı 6 da araştırma görevlisi olma sebebini "kendimi donanıml yetiştirmek" ifadesiyle ortaya koymuştur. Katılımcı 10 araştırma görevliliğini üretken bulduğu için seçtiğini "üretken bir meslek olduğunu düşündüğüm için" sözleriyle belirtirken, Katılımcı 3 de benzer açıklamalar yapmış̦ır: "Yani eğitim sistemine fayda sağlayabilecek kendimi yararl hissetmek istiyorum, güzel şeyler yapmak istiyorum, somut şeyler yapmak istiyorum, bu mesleğe girme sebebim bu."

Araştırma görevlilerinin yaşadıkları olumlu ve olumsuz deneyimlerin onların ileride nasıl bir akademisyen olacaklarına ilişkin bir algı oluşturduğu belirlenmiştir. Araştırma görevlilerinin bu süreç içerisinde akademik kimlik kazandıkları ve ileride hayatlarında uygulayacakları standartları bu süreçte belirledikleri de görülmüştür. Katılımcı 4, kendisinin sahip olduğu akademisyen konseptini araştırma görevliliği sürecinde inşa ettiğini şu cümlelerle belirtmiştir: "Ben doktoramı tamamlayabilirsem, bir gün olacağım hocanın nasıl biri olacağını aslında şu anda belirlemiş oluyorum. Yani kendime dair tasavvurum neyse, onu şimdi inşa ediyorum... Şimdi hangi duygularla yapıyorsam bu işi, hangi görev anlayışılla ilerde de öyle olacak." Katılımc1 9, "Doktora süreci zaten kişiliğinizin akademik anlamda oluşmasının en önemli aşaması" diyerek araştırma görevliliği sürecinde yaşadığı deneyimleri ileride akademik hayatına nasıl yansıtacağını şöyle açılklamıştır:

Kendim hoca olduğunda, nasipse olursam eğer, bireysel anlamda bu tip uygulamaların hiç birisini yapttrmayacağım, yapmayacağım da, söz veriyorum, namus sözü. Ayrıca sorumlu düzeyde bir koltuğa sahibi olduğumda, sözü geçer imza yetkisi olan bir koltukta, onları başkasının yapmasına da müsaade etmeyeceğgim. Bir hocanın getirip 500 kağıdı 
önüme koyup, bunları oku demesine müsaade edildi ama ben bir başkasının bu şekildeki uygulamaya maruz kalmasına izin vermeyeceğim inşallah.

Katılımcı 9'un bu sözleri yaşadığı sorunların kendisini meslek etiği konusunda oldukça duyarlı yaptığını, bunun sonucu olarak başkalarının da aynı olumsuz tecrübeleri yaşamamaları için etik ilkelere sadık bir akademisyen olmayı kendisine misyon edindiğini göstermektedir. Katılımcı 2'de yaşadığı olumsuz deneyimlerin diğer araştırma görevlileri tarafından yaşanmaması için ilerde nasıl bir akademik duruşa sahip olacağını da şu sözlerle ifade etmiştir: "Ben, burada yaşadı̆̆ım olumsuz durumları yükseldiğinde insanlara yansıtma. Senin yanında çalışanlara yansıtma. Araştırma görevlilerini el üstünde tut. Onları değerli gör. Değerli olduklarını hissettir diye içimden de her seferinde şartlanıyorum.” Katılımc1 9 ve Katılımc1 2, gözlem yoluyla öğrenme kuramına dolaylı olarak işaret ederek araştırma görevlilerinin bu süreçte yaşadığı sıkıntıları ileride kendi yanında çalışanlara da uygulayacaklarını söylemişlerdir. Örneğin, Katılımcı 2 bu durumu "O yüzden de zaten insanlar hoca olduklarından da öğretim üyesi olduklarında da aynı muameleyi görmeye devam ediyorlar ya da kendileri de başkalarına yapmaya devam ediyorlar" sözleriyle belirtmiştir. Katılımcı 5 de araştırma görevliliği sürecinde yaşadıklarının ileride nasıl bir akademisyen olmak istediğini etkilediğini söylemiştir.

\section{Akademik gelişim sağlama ve entelektüel doyum}

Çalışmaya katılan araştırma görevlilerinin araştırma görevliliği deneyimini akademik gelişim süreci olarak değerlendirdikleri de tespit edilmiştir. Araştırma görevlilerinin bu süreç içerisinde yaptıkları bilimsel çalışmaların ve yayınların onlara entelektüel doyum verdiği belirlenmiştir. Katılımc1 10, araştırma görevliliğine ilişkin yaşadığ1 tecrübeyi, "Her gün bir şeyin üzerine başka bir şey katmanız gerekiyor, her gün makale okumanız gerekiyor, alanınızı takip etmemiz lazım, bilgilerinizin güncel olması gerekiyor” diyerek ifade etmiştir. Katılımcı 8, araştırma görevliliğinin kendisi için ifade ettiği anlamı ise "Benim için araştırma görevliliği gerçekten bilimsel anlamda yenilikler sunulabilecek, alanında yeterli olan ve sürekli çalışmalar yapıp, yurtdışı yurtiçi çalışmaları yakından takip edebilen, aynı zamanda tabi bölümde de etkin olarak kişi anlamına geliyor" sözleriyle dile getirmiștir. Katılımcı 7, araştırma görevlisi olmayı "Araştırma görevlisi olmak demek sürekli üreten birisi olmak demektir. Aslında hep aynı yerde aynı konu üzerinde değil de, daha farklı düşünebilmektir” diyerek açıklamıştır. Katılımcı 2, sürekli bilimsel çalışmalarla ilgilenerek akademik gelişim sağlamaya çalıştığını şöyle açıklamıştır:

Nerdeyse her gün akademik şeylerle meşgulüz. Hafta sonları bile dışarı çıkmadığımı hatırlıyorum. Hafta sonları bile çeşitli makaleler üreteyim, bildiriler yazayım diye... Sürekli bir öğrenme çabası, gayreti içindesiniz. Kendinizi geliştirme gayretiniz sürekli devam ediyor. Böyle bir amacınız var. Ucu bucağı olmayan akademi alanının içindesiniz.

Katılımc1 9, akademik açıdan kat ettiği mesafeyi ve kendinde gördügü gelişimi şu şekilde ifade etmiştir: "Yaklaşık sekiz yıldır yapıyorum bu işi. Sekiz sene önceki ben ve şu anki ben arasındaki 
bilgi, beceri ve yaşantı farkllikları beni çok mutlu ediyor çünkü oradaki insan ile buradaki insan [arasında] bilgi ve deneyim açısından uçurumlar var." Katılımcı 8 de araştırma görevliliği süresince kendisini akademik açıdan geliştirdiğini "illk baştaki seviyeden daha ilerdeyim" diyerek dile getirmiştir. Katılımcı 3, araştırma görevliliği ile ilgili olarak "Yani kendini çok geliştirmesi gereken, bir haftası bir haftasına uymaması gereken meslek içerisindeyiz" sürekli kendilerini geliştirmek zorunda olduklarını söylemiştir. Benzer şekilde Katılımcı 1 de "Iş̧ hayatını dışarı da bıraktığın zaman sanki evde sürekli çalışmam gerekliymiş gibi bir algım oluştu. Eğer gerçekten iyi bir akademisyen olmayı iddia ediyorsan sürekli zamanımı buna ayırmam gerekiyor diye düşünüyorum" diyerek aynı gerekliliğe dikkat çekmiştir.

Araştırma yapma ve bunun sonucunda ortaya bir ürün çıkması araştırma görevlilerine entelektüel doyum vererek mutlu etmektedir. Katılımcı 2, bu durumu "Üretkenlik. O çok mutluluk verici olduğunu düşünüyorum. Şimdi, bildiri yazıyorsunuz. Bir makale üretiyorsunuz veya bir satır bir şey yazıyorsunuz. Bilime katkı sağladım diye, mutluluk veriyor" sözleriyle dile getirmiştir. Katılımcı 7, "Eğer bir çalışma yaptı isem, makalem yayınlanmışsa, ...o an için mutluyum" diyerek bilimsel ürün ortaya koymanın kendisine mutluluk verdiğini söylemiştir. Aynı katılımcı bilimsel çalışma üretmediği zaman yaşadığı olumsuz duyguyu ve yaptığı öz eleştiriyi ise "...kendimi kötü hissettiriyor... kendimi neden bir şey yapmadim diye eleştiriyorum" diyerek dile getirmiştir. Katılımcı 4, akademik çalışmalar yapmanın kendisinde uyandırdığı duyguları "Günlük olarak eğer tezim için bir şeyler yapabilmişsem tasarladığım kadar çalı̧abilmişsem, işin ufak tefek taraflarıyla değil de özüne iliş̧in bir takım şeyleri okuyabilmişsem bana iyi hissettiriyor... Bu iyi ve anlamlı iş duygusunu yaşatıyor" diyerek belirtmiştir. Katılımcı 9, bilimsel çalışma üretmeye yönelik yaptığı çalışmaları "Bilimsel anlamda yaptığım ürün beni mutlu ediyor" diyerek, Katılımcı 10 ise okuyup araştırmanın kendisine yaşattığı duyguyu "Mutluyum açıkçası. Çalışma hayatı ya da okuyup araştırdıkça insan bir şeyler ortaya koyduğunu düşünüyor" sözleriyle dile getirmiştir. Katılımc1 8 ise "Bu çalş̧maları araştırmaları yaptıkça işte makale olsun bildiri olsun sempozyumlara katılmak olsun daha yeni şeyler üretme hevesi oluyor" sözleriyle yapılan araştırmaların yeni yapılacak araştırmalar için teşvik edici olduğunu söylemiştir.

\section{Sonuç ve tartışma}

Eğitim fakültesindeki araştırma görevlileri için araştırma görevlisi olmanın ne anlama geldiğinin incelendiği bu çalışma sonucunda birbiriyle ilişkili alt bileşen tespit edilmiştir. Bunlar, araştırma görevlilerinin (1) istismar edilmesi: sekreterlik ve angarya işler yapması, (2) akademik baskıyla karşılaşması, (3) ekonomik sıkıntılarla yüzleşmesi, (4) motivasyon kaybı yaşaması, (5) akademik kariyer yapma ve kimlik kazanmast ve (6) akademik gelişim ve entelektüel doyumudur. $\mathrm{Bu}$ bölümde fenomenin yapısını oluşturan bileşenler, alanda yapılmış çalışmalar ışığında tartışlacaktır.

Çalışma sonucunda elde edilen bulgular araştırma görevlilerinin çalıştıkları birimlerdeki yöneticiler ve diğerëğretim üyeleri tarafından istismar edildiklerini ortaya koymaktadır. Araştırma görevlileri, akademik çalışmalarla hiçbir ilgisi olmayan sekreterlik işleri yaptıklarını, hocaların 
özel işlerini halletmek zorunda kaldıklarını ve çeşitli angarya işler yaptıklarını belirtmişlerdir. Araştırmanın bu bulgusu önceden farklı araştırma desenleri kullanılarak yürütülen çalışmalardan elde edilen bulgularla örtüşmektedir. Bakioğlu ve Pekince (2011)'nin çalışmasında, araştırma görevlilerinin çalıştıkları bölümdeki öğretim elemanlarının onları akademik araştırmalardan sorumlu kişiler olarak görmek yerine bölümün günlük işlerinin sürdürülmesinden sorumlu görevliler olarak gördükleri belirlenmiştir. Korkut, Muştan ve Yalçınkaya (1999) tarafından yapılan çalışmada iş tanımları arasında olmamasına rağmen araştırma görevlilerinin sekreterlik işleri yaptıkları rapor edilmiştir. Kısa (2013)'nın çalışmasında da araştırma görevlilerinin yaptıkları işlerden dolayı mesleklerini en çok 'çıraklık', 'sekreterlik,' 'joker' ve 'köle'liğe benzettikleri belirlenmiştir. Bu çalışmalardan elde edilen bulgulara benzer şekilde bu çalışmada da araştırma görevlileri, "angarya" olarak nitelendirdikleri işleri yapmak zorunda kaldıkları için kendilerini değersiz görülen bir 'hamala', bazen de 'sırtına semer vurulmuş' bir hayvana benzetmişlerdir. Araştırma görevlileri, sekreterlik işleri dışında ilaç yazdırma ve arabadan bir şey getirme gibi hocaların özel işlerini yaptıklarını, bu angaryalara ilaveten hocaların yerine dönemlik veya daha kısa süreli derslere girerek öğretim görevlisi gibi çalışmak zorunda kaldıklarını belirtmişlerdir. Korkut, Muştan ve Yalçınkaya (1999)'nın çalışmasında da araştırma görevlilerinin hocaların yerine derslere girdikleri tespit edilmiştir. Çalışmamızın bu bulgusu, Bakioğlu ve Yaman (2004)' yaptı̆̆ı araştırmanın bulguları ile de örtüşmektedir. İlgili çalışmadan elde edilen bulgulara göre, araştırma görevlilerinin \%76'sı öğretim üyelerinin işleriyle sürekli meşgul olmalarının kariyer gelişimlerini olumsuz etkilediğini düşünmektedirler. Çalışmamızda araştırma görevlilerinin görev tanımları dışında akademik olmayan işleri yapmak zorunda kalmaları mesleğe karşı tutumlarını ve motivasyonlarını olumsuz yönde etkilediği belirlenmiştir. Bakioğlu ve Yaman (2004) tarafından yapılan çalışma sonucunda da, araştırma görevlilerinin \% 75 ’ i eğitim faaliyetleri dışındaki işlerle meşgul olmanın akademik gelişimlerini olumsuz etkilediğini belirtmişlerdir.

Araştırma görevlilerinin görev tanımı "yükseköğretim kurumlarında yapilan araştırma, inceleme ve deneylerde yardımcı olan ve yetkili organlarca verilen ilgili diğer görevleri yapan öğretim yardımcılarıdır" şeklinde yapılmıştır (Yüksek Öğretim Kanunu [YÖK], 1981, madde 33). Bu tanımda yer alan "yetkili organlarca verilen ilgili diğer görevleri yapan" ifadesi diğer görevlerin ne olduğunu açılamakta yetersiz kalmaktadır. Görev tanımındaki bu belirsizlik önceki araştırma sonuçlarının ve bu çalışmanın ortaya koyduğu gibi araştırma görevlilerinin akademik baskıya maruz kalmalarına ve istismar edilmelerine zemin hazırlamaktadır. Araştırma görevlilerinin görev tanımlarında geçen "yetkili organlarca verilen ilgili diğer görevlerin" neler olduğu açıklığa kavuşturulmalıdır. Görevlerin türü ve hangi alanları kapsadığ istismara müsaade etmeyecek şekilde belirtilmelidir. Araştırma görevliliği kadrosunun sözleşmeli statüde olması araştırma görevlilerinin işten atılma veya sözleşmelerinin yenilenmemesi korkusu yaşamalarına sebep olmaktadır. Bu endişe ve korkuyu yoğun olarak yaşayan katılımcılardan birisi, kendisiyle yapılan mülakat ses kayıtlarının hiç kimseyle paylaşılmamasını şart koşmuş, isminin deşifre edilmesi halinde araştırmacılara dava açacağını söylemiştir. Çalışmaya davet edilen bazı araştırma görevlileri ise araştırma konusunu öğrenince kendilerine zarar gelecekleri endişesini dile getirerek çalışmaya katılmayı reddetmişlerdir. Araştırma görevlileri karşılaştıkları baskı ve 
istismarlar karşısında genellikle sessiz kalma eğilimi göstermektedirler. Bu sessiz tepkiyi anlamak zor değildir çünkü araştırma görevliliği akademik kariyerin ilk basamağını oluşturmaktadır. Diğer kadrolardaki öğretim üyeleri hiyerarşik olarak hem yetki hem de unvan açısından araştırma görevlilerinin üstünde yer almaktadır. Görev tanımının ucu açık yapılması daha üst unvanlara sahip akademisyenlerin araştırma görevlilerini kendi akademik çalışmalarında kullanılmalarına ve emeklerini istismar etmelerine firsat vermektedir. Araştırmamızdan elde ettiğimiz sonuçlar bu gerçeği açı bir şekilde gözler önüne sermektedir. Bakioğlu ve Yaman (2004)'in araştırma sonuçlarında da, araştırma görevlilerinin \%86'sının mesleki görev tanımının açık ve net olmamasının kariyer gelişimlerini olumsuz etkilediğini belirttikleri rapor edilmiştir.

Araştırmamızda ulaşılan bulgulara göre bazı öğretim üyelerinin yetersiz çalı̧̧aları araştırma görevlilerine vererek düzeltmelerini istedikleri veya araştırma görevlilerinin yaptıkları çalışmalara herhangi bir katkıda bulunmaksızın yazar olarak ortak oldukları tespit edilmiştir. Çalışmamıza katılan araştırma görevlilerinin birinci elden yaşadıkları deneyimler, meslek etiği zayıf öğretim üyelerinin araştırma görevlilerine karşı sergiledikleri tutum ve davranışlarının araştırma görevlilerinin kendilerini geliştirebilmelerinin önünde büyük bir engel oluşturduğunu göstermektedir. Çalışmamızda katılımcıların makale ve tez konusunun belirlenmesinden danışman seçimine kadar birçok alanda akademik müdahale ve sınırlandırmalarla karşılaştıkları belirlenmiştir. Araştırma görevlilerinin karşılaştıkları bu tür istismar, baskı ve müdahalelerin ortadan kaldırılmasında başta Yükseköğretim Kurulu olmak üzere, üniversite rektörleri, dekanlar, bölüm ve anabilim dalı başkanlarına önemli sorumluluklar düşmektedir. Öncelikle YÖK, araştırma görevlilerinin görev tanımını hiçbir belirsizliğe meydan vermeyecek şekilde spesifik olarak yapmalı, Türkiye'de bilimsel çalışmalarda yaşanan yaygın etik ihlallerini ve araştırma görevlilerinin sürekli yüzleştikleri sorunları göz önüne alarak hangi durumlarda araştırma görevlilerinin görevleri dışında kullanılmış olduklarını örneklerle betimleyen bir yönerge hazırlamalıdır. Bu yönerge hem öğretim üyeleri hem de araştırma görevlileri tarafından okunarak imzalanmalı, yönergenin uygulanması titizlikle takip edilmeli, yönergeye aykırı davranışlarda bulunan öğretim üyelerine gerekli yaptırımlar zamanında yapılmalıdır. Yüksek lisans ve doktora öğrenimleri sırasında kendilerinden ders alan araştırma görevlilerinin hazırladıkları projeleri sadece kendi adına yayınlatan öğretim üyeleri tespit edilmeli ve bunlar hakkında yasal işlemler başlatılmalıdır. Bu tür bilimsel hırsılıkların önüne geçilmesi için lisansüstü düzeyde verilen her ders için öğrencilerin hazırladıkları projeler fakültenin veya üniversitenin veri tabanlarına eklenmeli, herkesin erişimine açık olmalıdır.

Çalışmamızda ortaya çıkan sorunlardan bir diğeri araştırma görevlilerinin ekonomik baskı altında yaşadıkları gerçeğidir. Çalışmaya katılan araştırma görevlileri hem özel hayatlarında hem de bilimsel çalışmalarında ekonomik sorunlarla karşılaştıklarını, akademik birçok ihtiyaçlarını destek olmaksızın kendileri karşılamak zorunda kaldıklarını belirtmişlerdir. Korkut, Muştan ve Yalçınkaya (1999)'nın yaptığı çalışmada da, maddi yetersizliğin araştırma görevlileri için önemli bir sorun kaynağı olduğu, araştırma görevlilerinin araştırma fonlarından yeterli düzeyde yararlanamadıkları tespit edilmiştir. Çalışmamızda araştırma görevlilerinin geçimlerini sağlamakta zorlandıkları bu nedenle ek iş yaparak ekonomik sıkıntılarını hafifletmeye çalıştıkları 
görülmüştür. Bakioğlu ve Yaman (2004)'in çalışmasında da, araştırma görevlilerinin \% 52'sinin ekonomik sıkıntılardan dolayı ek iş yapmak zorunda kaldıkları belirtilmiştir. Korkut, Muştan ve Yalçınkaya (1999)'nın çalışmasında da benzer bulgulara ulaşılmış, çalışmaya katılan 1534 araştırma görevlisinin \%65,5’nin kirada oturduğu, \%82'sinin ise üniversiteden ayrılmak istediği, bu isteklerinin nedeni olarak maddi yetersizliği gösterdikleri belirlenmiştir. Terzi ve Sağlam’ın (2008) çalışmasında, araştırma görevlilerinin maaşlarının yetersiz olmasının mesleki tükenmişlik düzeylerini artırdığı sonucuna ulaşılmıştır. Çalışmamızın bulgularını destekler nitelikte, Avcı ve Pala (2004) tarafından yapılan çalışmada araştırma görevlilerinin bedensel, sosyal ve çevre alanında yaşam kalitesinin düşük olduğu belirlenmiştir (Avc1 ve Pala, 2004: 84). Bakioğlu ve Yaman (2004) tarafından yapılan çalışmada araştırma görevlilerinin üçte ikisi, kariyer çalışmalarının sosyal hayatlarını olumsuz etkilediğini belirtmişlerdir. Akademisyenliğin başlangıcı olan araştırma görevliliği, öğretim elemanları arasında geliri en az olan akademik kadrodur. Akademik hayata başlangıcın ilk adımı olan araştırma görevliliğinin maddi açıdan daha cazip hale getirilmesi üniversiteden mezun olan başarılı öğrencilerin bu mesleğe yönelmelerini sağlamak bakımından büyük önem arz etmektedir.

Akademisyenlik, sürekli kendini yenilemeyi gerektiren, belirli mesai saatleri ile sınırlı kalmayan bir meslektir. Akademisyenlerin bu sorumluluğu yerine getirebilmeleri mesleğe karşı olumlu bir tutum içinde olmalarını ve motivasyonlarının yüksek düzeyde olmasını gerektirmektedir (Yılmaz ve Özdemir, 2012: 51-52). Yaya (2011)'nın çalışmasında araştırma görevlilerinin mesleğe yönelik görüşlerinin ve tutumlarının mesleki çalışma yılına ve eğitim düzeylerindeki artışa paralel olarak olumsuz yönde yükseldiği sonucuna ulaşılmıştır. Bu sonuç, çalışmamızdan elde edilen bulguları destekler niteliktedir. Çalışmamızda, araştırma görevlilerinin çoğunun kendi denetimlerinde olmayan çeşitli sebeplerden dolayı motivasyonlarında düşme olduğu belirlenmiştir. Katılımcılar, göreve ilk başladıkları döneme göre motivasyonlarında önemli azalma hissettiklerini ifade etmişlerdir. Araştırma görevlilerinin motivasyon kaybı yaşama sebeplerinin başında akademik olmayan işlerle uğraşmak zorunda kalmaları gelmektedir. Araştırma bulgularımıza göre, araştırma görevlileri kendi mesleklerini daha çok akademik gelişim olarak görmektedirler. Fakat akademik çalışmalar yerine -bazı öğretim üyelerinin istismarı sonucu- farklı işlerle uğraşmak zorunda kalmaları motivasyonlarını olumsuz yönde etkilemektedir. Motivasyon kaybına neden olan diğer bir faktör araştırma görevlilerinin çalışmalarına yeterli ekonomik desteğin verilmemesidir. Motivasyon kaybına neden olan diğer önemli bir sebep ise araştırma görevlilerinin akademik özgürlüğe sahip olmak istemeleri ama bu isteğin meslek etiğine riayet etmeyen bazı öğretim üyelerinden gelen müdahaleler sonucu baskı altına alınması ve köreltilmesidir. Tez konusunun belirlenmesi ve danışman seçimi gibi konularda araştırma görevlilerinin fikirlerine değer verilmemesi ve baskı yapılması, onların mesleğe yönelik tutumunu olumsuz etkilemekte ve korkak olarak yetişmelerine sebep olmaktadır.

Çalışmamızdan elde edilen bulgular, araştırma görevliliği sürecinde edinilen deneyimlerin araştırma görevlilerinin ileride nasıl bir akademisyen olacaklarını veya nasıl bir kimliğe sahip olacaklarını belirlemede önemli bir rol oynadı̆̆ını göstermiştir. Katılımcılar, araştırma görevlisi olarak yaşadıkları deneyimlerin akademik kimlik inşa etme sürecinde önemli bir rol oynadığını 
açıkça belirtmişlerdir. Başka bir deyişle; araştırma görevlilerine baskı yapılması, özgürlüklerinin kısıtlanması ve görüşlerine değer verilmemesi onların akademik kimliklerini ve kişiliklerini olumsuz olarak etkilemektedir. Bunun sonucunda baskılara boyun eğen, haksızlıklar karşısında sessiz kalan ve medeni cesaretten yoksun akademisyenler yetişmektedir. Bulgular kısmında katılımcıların görüşme metinlerinden yapılan doğrudan alıntılar bu gerçeği yalın bir şekilde ortaya koymuştur. Katılımcılar, karşılaştıkları istismar ve baskılar karşısında sessiz kaldıklarını, tepkide bulunamadıklarını, kabullendiklerini ve sineye çektiklerini, yani bölüm başkanı ve kendilerini istismar eden diğer öğretim elemanlarından korktuklarını ifade etmişlerdir. Hatta bir katılımcı korkaklığın getirdiği bu kabullenmeyi bir metaforla açıklamış, araştırma görevliliğini sırtına semer vurulmuş bir eşeğe benzetmiş, bu semere mutlaka birilerinin bineceğini, kimin bineceğinin pek de önemli olmadığını, kendisinin bu durumu kabullendiğini belirtmiştir. Çalışmaya katılan diğer araştırma görevlilerinin ifadeleri de karşılaştıkları baskılar karşısında onurlu bir direniş göstermekten uzak olduklarını, bu sorunların ortadan kaldırılması için hiçbir teşebbüste bulunmadıklarını ortaya koymuştur.

Araşıırma görevlileri arasında öğrenilmiş çaresizliğin bu kadar yaygın olması ülkemiz adına endişe vericidir. Baskı ve yıldırma altında yaşayan araştırma görevlilerinin profesör olduklarında da kendilerinden bir üst mevkide veya daha fazla yetkiye sahip olan devlet görevlilerinden çekinerek onların hukuk dışı emirlerine boyun eğme eğilimleri oldukça yüksektir. Bunun örneklerini ülkemizin yakın geçmişine baktığımızda görmek mümkündür. Bir örnek vermek gerekirse, "28 Şubat" sürecinde ordudan gelen baskı ve yönlendirmeler sonucunda bazı akademisyenler postmodern darbeyi destekleyen basın açıklamaları yapmışlar, bu amaçla sokaklarda cübbeli yürüyüşler düzenlemişlerdir. Özgür düşünceyi ve demokratik değerleri temsil etmesi gereken akademisyenlerin darbe taraftarı bu düşünce ve davranışları milli hafızada tazeliğini halen korumaktadır. Üniversitelerde görülen bu tür olumsuzlukların önüne geçmek için, toplumun önünde meşale olacak, hakkı ve doğruyu her yerde haykıracak, kimseden korkmayacak, gerekirse bölüm başkanı, dekan, rektör ve YÖK başkanını ilgili mercilere şikâyet etmekten çekinmeyecek cesur akademisyenlerin yetiştirilmesine şiddetle ihtiyaç vardır. Bu amaç doğrultusunda öncelikli olarak araştırma görevlilerine sırtında semer taşımayı kabullenmenin insan onuruna yakışmayacağı, 'onurlu' bir hayat sürmenin her şeyin üstünde olduğu inancını yerleştirecek çalışmaların yapılmasına ihtiyaç vardır. Kanun ve yönetmeliklerle veya yargı yoluyla etkili bir şekilde bu tür sorunların üstesinden gelinemediği ortadadır. Kanunlar yürürlüktedir ama bu kanunların hayata geçirilmesi için inanca, cesarete ve mücadeleci bir ruha ihtiyaç vardır. Haksızlık yapan, zalim, baskıcı ve çevresindeki insanları istismar etmeye alışmış insanlarla mücadele edilmesi gerektiği inancı araştırma görevlilerine kazandırılmalıdır. $\mathrm{Bu}$ amaç doğrultusunda araştırma görevliliği oryantasyon programları veya hizmet-içi eğitim seminerleri düzenlenmelidir. Bu oryantasyon programlarında istismarlara ve baskılara boyun eğmeyerek mücadele eden akademisyenlerin deneyimlerinden yararlanılmalı ve idari yargıya taşıyıp kazandıkları davalar ele alınmalıdır. Tüm araştırma görevlilerine yargı yoluyla kendilerine yapılan yanlışlıklara karşı mücadele etme ve hak arama alışkanlığı kazandırılmalı ve 'sözleşmem yenilenmez' korkusunu aşmaları sağlanmalıdır. 
Öğretim programlarında 'yapılandırmacılıktan' (constructivism) çok toplumdaki eşitsizliği, adaletsizliği ve haksızlığı ortadan kaldırarak sosyal değişimi ve adil bir toplumsal yapıyı hedefleyen 'yeniden yapılandırmacılığın' (re-constructivism) prensiplerinin uygulanmasına daha fazla ağırlık verilmelidir. Diktatörlerin egemenliklerinin ve oluşturdukları baskıların nasıl bertaraf edileceğine dair teoriler üreten ve kitaplar yazan Amerikalı emekli öğretim üyesi Prof. Dr. Gene Sharp’n eserlerinde belirttiği demokratik başkaldırı yöntemleri ve taktikleri de araştırma görevlilerine öğretilmelidir. Brezilyalı eleştirel pedagog Paulo Freire gibi yazarların fikirlerinden de yararlanılmalıdır. Son olarak araştırma görevlileri üzerinde baskı kuran öğretim üyeleri tespit edilmeli, onları bu davranışlarından vazgeçirecek gerekli yaptırımlar ve yasal düzenlemeler yapılmalıdır. Meslek etiği konusunda tüm akademisyenlere çeşitli platformlarda eğitimler verilmelidir.

Araştırma bulgularında dikkat çeken diğer önemli bir nokta ise araştırma görevlilerinin özeleştiri yapmaktan çekinmiş olmalarıdır. Araştırma görevlileri öğretim üyelerine birçok eleştiri yöneltmişlerdir ama kendilerine veya diğer araştırma görevlilerine yönelik eleştiri yapmamışlardır. Başka bir deyişle görevini layıkıyla yapmayan araştırma görevlilerine hiçbir söz söylememişlerdir. Öğretim üyeleri arasında mesleklerini etik ilkelere uygun yapmayanlar olabilir ama bu durum araştırma görevlileri için de geçerlidir. Bu nedenle, araştırma sonuçlarından öğretim üyelerinin hepsinin kötü olduğu ve araştırma görevlilerini istismar ettikleri veya araştırma görevlilerinin hepsinin iyi olduğu şeklinde bir genellemeye varılmamalıdır. Araştırma deseni de böyle bir genellemeye imkân vermemektedir. Çalışma nitel araştırma yöntemi kullanılarak fenomenolojik araştırma deseni ile yürütülmüştür. Bu çalışma deseninde az sayıda katılımcının deneyimlerime yükledikleri anlam derinlemesine incelenerek betimlenir. Katılımcı sayısı az olduğu için elde edilen sonuçlar genelleme yapmaya uygun değildir. Bu nedenle, bu çalışmadan elde edilen bulgular tüm öğretim üyelerine veya araştırma görevlilerine genellenemez. Araştırma sonuçlarının yorumlanmasında bu sınırlılık göz önüne alınmalıdır. 


\section{Kaynaklar}

Avcı, K. ve Pala, K.(2004). Uludağ üniversitesi tıp fakültesinde çalışan araştırma görevlisi ve uzman doktorların yaşam kalitesinin değerlendirilmesi. Uludağ Üniversitesi Tip Fakültesi Dergisi, 30(2), 81-85.

Aypay, A. (2006). Üniversitelerde akademik etkinlik ve örgütsel davranış arasındaki ilişki. Kuram ve Uygulamada Eğitim Yönetimi Dergisi, 12(2), 175-198.

Aytaç, S. (2005). Çalışanların işlerine ilişkin duygularının stres tepkileri üzerindeki etkisi. İstanbul Üniversitesi İktisat Fakültesi Mecmuasl, 55(1), 834-851.

Bakioğlu, A ve Yaman, E. (2004). Araştırma görevlilerinin kariyer gelişimleri: Engeller ve çözümler. M.Ü. Atatürk Eğitim Fakültesi Eğitim Bilimleri Dergisi, 20, s.1-20.

Bakioğlu, A. ve Pekince, D.(2011) Araştırma görevlilerinin kariyer gelişimlerine bölümlerdeki destek kültürünün etkisi. Uluslararası Yüksek Öğretim Kongresi: Yeni Yönelimler ve Sorunlar. 2. Cilt/ Bölüm XI, s.1272-1280.

Bayar, S. A. ve Bayar, V. (2012). Akademisyen ve öğrencilerin araştırma görevliliğine ilişkin metaforik algıları. Eğitimde Politika Analizi Dergisi, 1(1), 26-48.

Baran, D. Paliç, G. (2012). Akademisyenlerin akademik kariyere yönelik tutumların incelenmesi. Journal Of Educational And Instructional Studies In The World. 2 (1), 96-101

Boylu, Y., Pelit, E., ve Güçer, E. (2007). Akademisyenlerin örgütsel bağlllık düzeyleri üzerine bir araştırma. Finans Politik \& Ekonomik Yorumlar, 44(511), 55-74.

Denscombe, M. (2007). The good research guide. New York: Open University Press \& McGraw-Hill Education.

Giorgi, A. (2009). The descriptive phenomenological method in psychology: A modified husserlian approach. Pittsburgh: Duquesne University Press.

Girgin, C. ve Arığlu, E. (2003). Üniversitelerimize toplu bakış ve yayın etkinliklerinin çeşitli göstergelerle analizi. Bilim ve Ütopya Temmuz.

İnand,, Y., Tunç, B., ve Uslu, F. (2013). Eğitim fakültesi öğretim elemanlarının kariyer engelleri ile iş doyumları arasındaki ilişski. Eğitim Bilimleri Araştırma Dergisi, 3(1).

Kısa, N. (2013). Araştırma görevlilerinin metaforik algıları: Kim onlar? Kim olmalılar?. Mehmet Akif Ersoy Üniversitesi Eğitim Fakültesi Dergisi, 28, 47-66

Korkut, H., Muştan, T., ve Yalçınkaya, M. (1999). Araştırma görevlilerinin sorunları. Kuram ve Uygulamada Eğitim Yönetimi Dergisi, 17, 19-36.

Kuşdil, E., Bayram, N., Aytaç, S. ve Bilgel, N. (2004). Çalışma yaşamında bireylerin yaptıkları işe ilişkin duygularının iş stres tepkileri üzerine etkisi. Endüstri İlişkileri ve İnsan Kaynakları Dergisi, 6(1).

Locke, E.A. (1968). What is job satisfaction? http://eric.ed.gov/?id=ED023138 adresinden 10 Temmuz 2014 tarihinde indirilmiştir.

Necşo1, D. V. (2011). Stress and job satisfaction among University teachers. Anxiety, 20, 13-17.

Terpstra, D. E., \& Honoree, A. L. (2004). Job satisfaction and pay satisfaction levels of university faculty by discipline type and by geographic region. Education, 124(3), 528.

Terzi, Y. ve Sağlam, V. (2008). Araştırma görevlilerinin mesleki tükenmişlik durumu. e-journal of New World Sciences Academy, 3(1), s.52-58.

Titchen, A. andHobson, D. (2005). Phenomenology. B. Somekh, C. Lewin (Edit.), Research methods in the social sciences (121-130). İngiltere: SAGE Publications.

Toker, B. (2011). Job satisfaction of academic staff: an empirical study on Turkey. Quality Assurance in Education, 19(2), 156-169. 
Yaya, D. (2011). Eğitim fakültelerindeki araştırma görevlilerinin çalışma yaşamlarına ilişkin görüşleri. (Yayınlanmamış Yüksek Lisans Tezi), Hacettepe Üniversitesi, Ankara.

Yılmaz, E.,\& Özdemir, G. (2012). Türkiye’de kadın akademisyen ve araştırmacıların karşılaştıkları sorunlar ve tarıma bakış açıları. Tekirdă̆ Ziraat Fakültesi Dergisi, 9(2).

Yıldırım, A. ve Simsek, H. (2006). Sosyal bilimlerde nitel araştırma yöntemleri. Ankara: Seçkin Yayıncılık.

YÖK (1981). Yüksek Öğretim Kanunu. http://mevzuat.basbakanlik.gov.tr/Metin.Aspx?MevzuatKod= 1.5.2547ઐMevzuatIliski=0ઐsourceXmlSearch=adresinden 23 Haziran 2014 tarihinde indirilmiştir. 